\title{
Heifer management characterization in dairy herds from the west of Buenos Aires, Argentina
}

\section{Caracterização da gestão de novilhas em rebanhos leiteiros do oeste de Buenos Aires, Argentina}

\author{
Federico Demateis Llera ${ }^{1}$ (D); Claudina Vissio ${ }^{2,3}$; María Paula Turiello²; María Alejandra Herrero \\ Alejandro José Larriestra ${ }^{2,5}$

\footnotetext{
${ }^{1}$ Agencia de Extensión Rural Trenque Lauquen, Instituto Nacional de Tecnología Agropecuaria, Buenos Aires, Argentina ${ }^{2}$ Universidad Nacional de Río Cuarto, Facultad de Agronomía y Veterinaria, Córdoba, Argentina

${ }^{3}$ Universidad Nacional de Río Cuarto, Instituto para el Desarrollo Agroindustrial y de la Salud CONICET, Córdoba, Argentina

${ }^{4}$ Universidad de Buenos Aires, Buenos Aires, Argentina

${ }^{5}$ Universidad Nacional de Villa María, Córdoba, Argentina
}

\begin{abstract}
The replacement program in a dairy farm represents the second or third largest cost in a dairy operation. This study aimed to characterize and typify the practices related to the dairy heifer replacement program and describe the growth, development, and health parameters during this period in commercial dairy herds in Trenque Lauquen. A cross-sectional observational study was carried out, including 54 randomly selected dairy farms that were visited once to collect data about facilities and management through a semi-structured survey. Cluster and principal coordinates analysis were applied to classify the farms based on all variables collected, grouped in four main areas: pre-fresh cows, colostrum management, pre-weaning calf's management, and personnel. Additionally, growth, development, and health status were also recorded and described for calves and breeding heifers. Two similar-sized farm clusters were identified with differences in management and facilities in different areas of calves rearing. In one cluster there was a greater proportion of farms having a pre-fresh group, implementing appropriate health (colostrum, vaccination) and feeding management. Also, differences in personnel and technical support were relevant. The estimated body gain was 452 and $774 \mathrm{~g} / \mathrm{d}$ for calves younger or older than $60 \mathrm{~d}$ of age, respectively. The age and weight farm averages in breeding heifers were 21.0 mo (range: 16.7-27.5) and $416.3 \mathrm{~kg}$ (range: 336.7-519.3), respectively. Diarrhea and respiratory affections were the major problems in pre-weaning calves and heifer rearing, respectively. The median mortality was $7.3,7.6$, and $2.9 \%$ at the calving, pre-weaning, and heifer rearing period, respectively. The results showed an improvement opportunity for producers, the design of precise and high impact programs that could lead to an improved replacement program.
\end{abstract}

Keywords: Calf rearing. Herd typification. Age at first service.

\section{RESUMO}

Nos rebanhos leiteiros, o programa de reposição representa o segundo ou o terceiro maior custo da atividade de produção de leite. O objetivo do presente trabalho foi caracterizar e tipificar as práticas relacionadas ao programa de reposição de novilhas leiteiras e descrever o crescimento, desenvolvimento e parâmetros de saúde durante este período em rebanhos leiteiros comerciais localizados em Trenque Lauquen, oeste de Buenos Aires, Argentina. Foi realizado um estudo observacional transversal incluindo 54 fazendas de produção de leite selecionadas ao acaso e visitadas uma única vez para a colheita de dados relacionados a instalações e manejo empregando-se um questionário semi-estruturado. Foi efetuada a análise dos agrupamentos e das coordenadas principais para classificar as fazendas com base em todas as variáveis colhidas e agrupadas em quatro principais áreas: vacas pré-parto, manejo de colostro, manejo pré-desmame de bezerros e recursos humanos. Os dados referentes ao crescimento, desenvolvimento e estado de saúde dos animais também foram registrados e descritos para bezerros e novilhas. Dois grupos de fazendas de tamanho semelhante foram identificados com diferenças no manejo e instalações em distintas áreas de recria de bezerros. Em um grupo houve uma maior proporção de fazendas que tinham um grupo de vacas pré-parto, com implementação de adequado manejo de saúde (colostro, vacinações) e manejo alimentar. Também foram relevantes as diferenças em termos de pessoal e suporte técnico. O ganho de peso estimado foi de 452 e 774 gramas por dia, respectivamente, para os bezerros jovens e os com idade superior a 60 dias. As médias das fazendas da idade e do peso das novilhas de reprodução foram, 
respectivamente, 21,0 meses (variação de 16,7 a 27,5) e 416,3 $\mathrm{kg}$ (variação de 336,7 a 519,3). A diarreia e as afecções respiratórias foram os maiores problemas de saúde, respectivamente, nos bezerros em pré-desmama e novilhas em recria. A média de mortalidade foi de 7,3; 7,6 e 2,9\%, respectivamente, ao parto, na pré-desmama e durante a recria de novilhas. Os resultados obtidos demonstraram a existência de oportunidades de melhoria para os produtores, com o delineamento de programas precisos e de alto impacto que poderão propiciar um programa de reposição aprimorado. Palavras-chave: Recria de bezerros. Tipificação de rebanhos. Idade do primeiro serviço.

\section{Correspondence to:}

Federico Demateis Llera

Agencia de Extensión Rural Trenque Lauquen, Instituto

Nacional de Tecnología Agropecuaria

Tte. Gral. Uriburu, 259

B6400, Trenque Lauquen, Provincia de Buenos Aires,

Argentina

e-mail: demateis.federico@inta.gob.ar

Received: December 02, 2020

Approved: June 23, 2021

How to cite: Demateis Llera F, Vissio C, Turiello MP, Herrero A, Larriestra J. Heifer management characterization in dairy herds from the west of Buenos Aires, Argentina. Braz J Vet Res Anim Sci. 2021;58:e178793. https://doi. org/10.11606/issn.1678-4456.bjvras.2021.178793

\section{Introduction}

The replacement program in a dairy farm impacts the lactating group size and its genetic improvement (Cabrera, 2012; Groenendaal et al., 2004; Mellado et al., 2014). This program represents the second or third largest cost in the dairy operation after considering lactating cow costs and labor (Larriestra 1993; Mellado et al. 2014).

The management of the replacement heifers to improve health and growth is a well-known topic (Vasseur et al. 2010a). Different studies about pre-fresh management (Brandão et al., 2016; Drackley, 2008; Garry et al., 2007), colostrum administration (Godden, 2008; McGuirk, 2008; Raboisson et al., 2016), nutrition during the preweaning phase (Davis \& Drackley, 2001; Jasper \& Weary, 2002; Khan et al., 2007; Lagger, 2010), personnel training (Garry et al., 2007; Hussain \& Priya, 2016; Jenny et al., 1981; Ullah \& Zheng, 2011), heifer growth and development monitoring (Heinrichs et al., 2005; Losinger and Heinrichs, 1997), among others, have been published showing their productive and economic benefits.

The knowledge about replacement heifer management allowed the development of tools to check, register, and monitor the on-farm practices (Vasseur et al., 2010b). However, the application of that knowledge is still an issue in Argentina and other places around the world
(Demateis Llera, 2015; Hötzel et al., 2014; Schild et al., 2020; Vasseur et al., 2010b). Typification methodologies allow the identification of practice adoption profiles among producers (Castel et al., 2010; Escobar \& Berdegué, 1990; Gaspar et al., 2008). This methodology has been applied in different dairy areas (Rampone et al., 2015; Vissio et al., 2013) and could lead to the design of high-impact extension programs for replacement dairy heifers.

This study aimed to characterize and typify the practices related to the dairy heifer replacement program and describe growth, development, and health parameters during this period in commercial dairy herds.

\section{Materials and Methods}

\section{Study population}

A cross-sectional observational study was carried out during April and March 2016 in Trenque Lauquen County, one of the largest counties in terms of milk production in Buenos Aires province (SENASA, 2015). The data set of dairy farms enrolled in the National Organization for the Vaccination of Foot and Mouth includes 160 total farms, and $66 \%$ of them had a size of 60 to 400 cows. Within that stratum, 54 farms were blocked by size (size 1: 60-120, size 2: $120-200$, size 3: 200-300, and size 4: 300-400 total cows) and randomly selected (Thrusfield and Christley, 2018).

\section{Data collection}

Farms were visited once to collect information about facilities and management, and growth, development, and health. Facilities and management were assessed with a semi-structured questionnaire conducted to the farm owner to collect information about 4 main areas: pre-fresh cows (4 variables), colostrum management (9 variables), pre-weaning calves management (18 variables), and personnel (5 variables), all based on published research studies (Pereyra et al., 2015; Tiranti et al., 2011; Vasseur et al., 2010a). In addition, heart girth and withers height of pre-weaned calves and breeding heifers were measured to assess growth parameters (Heinrichs et al., 2007). Also in the same visit, diarrhea and respiratory affections were recorded following the guidelines of McGuirk (2008). 
Morbidity was estimated as the number of calves with diarrhea or respiratory symptoms divided by the total number of animals on the same day. Data of born and dead calves from 2015 were also collected from the registration provided by the farm owner. Mortality was determined as the total number of dead calves divided by the number of born calves during the calendar year 2015 .

\section{Data analysis}

The data collected through the questionnaire was described using relative and absolute frequencies. Afterward, within each of the 4 areas, a multiple correspondence analysis was applied (Greenacre, 1984) to select the variables with the highest inertia on axis 1 . Finally, to classify the farms, all the selected variables were evaluated both using cluster analysis and principal coordinates analysis (Hair et al., 1998).

Weight, height, and age distributions were described at the herd level using median and quartiles. The growth rate for pre-weaning calves was estimated fitting a linear regression model, considering age as a predictor of live weight, and adjusting that by the herd (Thrusfield and Christley, 2018). Morbidity was estimated as the number of calves with diarrhea or respiratory affections divided by the total number of animals on the same day. Mortality was determined as the total number of dead calves divided by the number of born calves during the calendar year 2015. Morbidity and mortality data were then described overall and at the herd level.

\section{Results and Discussion}

From a total of 54 farms, 8 refused to participate resulting in 46 farms being evaluated. Response rates were 81.3, 90.9, 81.8 , and $70.0 \%$ for size blocks $1,2,3$, and 4 , respectively. This overall response rate is considered appropriate for interview-based studies (Singleton and Straits, 2010). Results from this study could be generalized for similarsized diaries in the region, as farms were selected by random stratified sampling, assuring representativeness (Thrusfield and Christley, 2018). Because of the response rate and the sampling design we assumed there was little response bias (Dunn et al., 2004).

According to the survey results, deficiencies in surveillance and facilities for calving were registered (Table 1). The lack of a pre-fresh cow group could mean less control over the last period of gestation, with negative consequences for the calf (Tao et al., 2012) and no specific diet formulation for the cow (Quigley and Drewry, 1998). Incorrect pre-fresh cow management could also increase the incidence of dystocia (Mee, 2008) and limit calf welfare (Vasseur et al. 2010a).

The colostrum administration was only accomplished systematically by $28 \%$ of the farms visited (Table 2 ), similar to the percentage reported in the Trenque Lauquen region before (Demateis Llera, 2015). It has been proved that this practice is cost-effective (Raboisson et al., 2016), as low serum immunoglobulin concentration is related to high morbidity and mortality rates (Godden, 2008; Kehoe et al., 2007; Tiranti et al., 2015). Some deficiencies were found within farms implementing this practice, like colostrum feeding after $12 \mathrm{~h}$ of life and less than the recommended volumes of colostrum. Those errors contributed to the lack of efficacy of this broadly validated practice (Godden, 2008; Rocha et al., 1998; Tiranti et al., 2015). In addition, the lack of quality and quantity colostrum evaluation, as registered in some farms, would also increase uncertainty (Buczinski et al., 2018).

Most of the farms fed their calves with restricted amounts of milk (4 L/d; Table 3 ) with the purpose of early stimulation of feed starter consumption. This could explain the low growth rates achieved as mentioned above (Rosenberger et al., 2017). One of the goals of the pre-weaning period is the duplication of weight from birth to weaning (Hammon et al., 2002; Jasper and Weary, 2002). But under a conventional feeding program (4 L of milk per day), such requirements are not met (Davis \& Drackley, 2001;

Table 1 - Herd descriptors about pre-fresh cow area for the random sample of dairy farms from Trenque Lauquen, Argentina (2016)

\begin{tabular}{|c|c|c|c|c|}
\hline Variables & Classes & $\begin{array}{c}\text { Number of } \\
\text { farms }\end{array}$ & $\begin{array}{c}\text { Frequency } \\
(\%)\end{array}$ & $\mathrm{Cl} 95 \%$ \\
\hline \multirow[t]{3}{*}{ Prefresh pen $(n=46)$} & No & 16 & 35 & $20-50$ \\
\hline & Yes, permanent place & 12 & 26 & $12-40$ \\
\hline & Yes, alternating place & 18 & 39 & $24-54$ \\
\hline \multirow[t]{2}{*}{ Calving assistance facilities $(n=44)$} & No & 18 & 41 & $25-57$ \\
\hline & Yes & 26 & 59 & $43-75$ \\
\hline \multirow{3}{*}{$\begin{array}{l}\text { Personnel house distance to prefresh } \\
\text { pen }(n=46)\end{array}$} & 50 to $100 \mathrm{~m}$ & 15 & 33 & $18-47$ \\
\hline & $<50 \mathrm{~m}$ & 8 & 17 & $5-29$ \\
\hline & $>100 \mathrm{~m}$ & 23 & 50 & $34-66$ \\
\hline \multirow[t]{2}{*}{ Prefresh cow vaccination $(n=46)$} & No & 28 & 61 & $46-76$ \\
\hline & Yes & 18 & 39 & $24-54$ \\
\hline
\end{tabular}


Table 2 - Herd descriptors about colostrum management for the random sample of dairy farms from Trenque Lauquen, Argentina (2016)

\begin{tabular}{|c|c|c|c|c|}
\hline Variables & Classes & $\begin{array}{c}\text { Number of } \\
\text { farms }\end{array}$ & $\begin{array}{c}\text { Frequency } \\
(\%)\end{array}$ & Cl 95\% \\
\hline \multirow[t]{2}{*}{ Systematic colostrum feeding $(n=46)$} & No & 33 & 72 & $58-86$ \\
\hline & Yes & 13 & 28 & $14-42$ \\
\hline \multirow[t]{2}{*}{ Stock of colostrum $(n=46)$} & No & 27 & 59 & $43-74$ \\
\hline & Yes & 19 & 41 & $26-57$ \\
\hline \multirow[t]{3}{*}{ Time of the $1^{\text {st }}$ colostrum meal $(n=46)$} & Natural suckling & 33 & 72 & $58-86$ \\
\hline & Within $1^{\text {st }} 12 \mathrm{~h}$ of life & 9 & 2 & $7-32$ \\
\hline & After $1^{\text {st }} 12 \mathrm{~h}$ of life & 4 & 09 & $2-21$ \\
\hline \multirow[t]{3}{*}{ Colostrum quantity fed $(n=46)$} & $<10 \%$ BW & 6 & 13 & $2-24$ \\
\hline & $>10 \% \mathrm{BW}$ & 7 & 15 & $4-27$ \\
\hline & Natural suckling & 33 & 72 & $58-86$ \\
\hline \multirow[t]{3}{*}{ Colostrum feeding method $(n=46)$} & Natural suckling & 33 & 72 & $58-86$ \\
\hline & Esophageal tube & 1 & 2 & $0-12$ \\
\hline & Bottle & 12 & 26 & $12-40$ \\
\hline \multirow[t]{3}{*}{ Colostrum meals $(n=46)$} & Natural suckling & 33 & 72 & $58-86$ \\
\hline & 1 meal & 7 & 15 & $4-27$ \\
\hline & 2 o more meals & 6 & 13 & $2-24$ \\
\hline \multirow[t]{4}{*}{ Colostrum quality assessment $(n=46)$} & None & 43 & 93 & $82-99$ \\
\hline & Colostrometer & 2 & 4 & $1-15$ \\
\hline & Refractometer & 0 & 0 & $0-8$ \\
\hline & Visual & 1 & 2 & $0-12$ \\
\hline \multirow[t]{2}{*}{ Colostrum heat treatment $(n=46)$} & Yes & 0 & 0 & $0-8$ \\
\hline & No & 46 & 1 & $92-100$ \\
\hline \multirow[t]{2}{*}{ Evaluation of passive transfer $(n=46)$} & Yes & 1 & 2 & $0-12$ \\
\hline & No & 45 & 98 & $88-100$ \\
\hline
\end{tabular}

Kiezebrink et al., 2015), while intensified or accelerated feeding programs have succeeded (Jasper and Weary, 2002; Kertz et al., 2017). More than half the farms offered water to the calves just once a day (Table 3 ), even though water is an essential nutrient making up 65 to $75 \%$ of the calf's body (Drackley, 2008). Limiting water intake could decrease starter intake and lead to lower growth rates (Davis \& Drackley, 2001). The starter was provided from the 1st month of life in $25 \%$ of the farms (Table 3 ). This could delay rumen development (Khan et al., 2007; Roth et al., 2009) and extend the period of liquid feed feeding, as shown in $33 \%$ of the calves evaluated.

Personnel involved in the pre-weaning area were affected by other activities on the farm and showed a relatively low level of formal and informal education (Table 4). Both aspects are relevant to get positive results in the rearing period (Hussain and Priya, 2016). Trained personnel provided with appropriate working protocols contribute to complying with standardized procedures and enhance the results in calf health and survival (Garry et al., 2007; Hussain \& Priya, 2016). Although previous studies showed that proper human resources management leads to lower staff turnover rates and better economic results (Ullah and Zheng, 2011), half the farms visited had employees with less than 2 years in service (Table 4 ). Only $34 \%$ of the farms had continuous technical support (Table 4), even though uninterrupted technical support is one of the ways to promote good management practices implementation (Vissio et al., 2013).

Two similar-sized clusters were identified, although predominant herd sizes included in cluster 1 were smaller than in cluster 2 (Table 5). The difference in herd size between clusters could explain some but not all the differences in good management practices implementation (Gargiulo et al., 2018), as 33\% of the farms in cluster 2 had less than 200 cows. In general, this cluster showed a greater proportion of farms having a pre-fresh group, implementing appropriate health (colostrum administraion, vaccination), and feeding management. Also, differences in personnel and technical support between clusters were relevant. Deficiencies detected in cluster 1 are important for calf health and could affect herd efficiency. Clustering analysis has previously been applied to classify small and medium-size dairy herds in Argentina considering management mastitis control schemes (Vissio et al., 2013), identifying two clusters where farms differed in having or 
Table 3 - Herd descriptors about pre-weaning calves management for the random sample of dairy farms from Trenque Lauquen, Argentina (2016)

\begin{tabular}{|c|c|c|c|c|}
\hline Variables & Classes & $\begin{array}{c}\text { Number of } \\
\text { farms }\end{array}$ & $\begin{array}{c}\text { Frequency } \\
\text { (\%) }\end{array}$ & $\mathrm{Cl} 95 \%$ \\
\hline \multirow[t]{2}{*}{ System ( $n=46)$} & Collective & 11 & 24 & $11-37$ \\
\hline & Individual & 35 & 76 & $63-90$ \\
\hline \multirow[t]{2}{*}{ Pre-weaning program initiation $(n=46)$} & Within the 1 st 24 hs & 18 & 39 & $24-54$ \\
\hline & After the 1 st $24 \mathrm{hs}$ & 28 & 61 & $46-76$ \\
\hline \multirow[t]{2}{*}{ Navel disinfection $(n=46)$} & Yes & 24 & 52 & $37-68$ \\
\hline & No & 22 & 48 & $32-63$ \\
\hline \multirow[t]{2}{*}{ Calf identification $(n=46)$} & Yes & 37 & 8 & $68-93$ \\
\hline & No & 9 & 2 & $7-32$ \\
\hline \multirow[t]{3}{*}{ Shelter $(n=46)$} & Correct & 6 & 13 & $2-34$ \\
\hline & Scarce & 39 & 85 & $73-96$ \\
\hline & None & 1 & 02 & $0-12$ \\
\hline \multirow[t]{2}{*}{ Calf place rotation $(n=46)$} & Yes & 39 & 85 & $73-96$ \\
\hline & No & 7 & 15 & $4-27$ \\
\hline \multirow[t]{2}{*}{ Bucket hygiene $(n=43)$} & Every day & 6 & 14 & $2-34$ \\
\hline & Once a week or less frequently & 37 & 86 & $68-93$ \\
\hline \multirow[t]{2}{*}{ Milk temperature measurement $(n=46)$} & Yes & 16 & 35 & $20-50$ \\
\hline & No & 30 & 65 & $50-80$ \\
\hline \multirow[t]{4}{*}{ Water provision $(n=46)$} & All day long & 10 & 22 & $9-35$ \\
\hline & Twice a day & 6 & 13 & $2-34$ \\
\hline & Once a day & 25 & 54 & $39-70$ \\
\hline & Not provided & 5 & 11 & $4-24$ \\
\hline \multirow[t]{4}{*}{ Weaning criteria $(n=46)$} & Age & 7 & 15 & $4-27$ \\
\hline & Visual appreciation & 17 & 37 & $22-52$ \\
\hline & Age and visual appreciation & 22 & 48 & $32-63$ \\
\hline & Starter intake & 0 & 0 & $0-8$ \\
\hline \multirow[t]{2}{*}{ Weaning method $(n=46)$} & Abrupt & 9 & 2 & $7-32$ \\
\hline & Gradual & 37 & 8 & $68-93$ \\
\hline \multirow[t]{2}{*}{ Transition pen for weaned calves $(n=46)$} & Yes & 30 & 65 & $50-80$ \\
\hline & No & 16 & 35 & $20-50$ \\
\hline \multirow[t]{3}{*}{ Liquid feed type ( $n=46)$} & Waste milk & 25 & 54 & $39-70$ \\
\hline & Saleable milk & 16 & 35 & $20-50$ \\
\hline & Milk replacer & 5 & 11 & $4-24$ \\
\hline \multirow[t]{3}{*}{ Liquid feed quantity $(n=46)$} & $>$ than $4 \mathrm{~L} / \mathrm{d}$ & 3 & 07 & $1-18$ \\
\hline & $4 \mathrm{~L} / \mathrm{d}$ & 34 & 74 & $60-88$ \\
\hline & Stepped program & 9 & 2 & $7-32$ \\
\hline \multirow[t]{2}{*}{ Liquid feed meals $(n=46)$} & 1 & 1 & 02 & $0-12$ \\
\hline & 2 & 45 & 98 & $88-100$ \\
\hline \multirow[t]{2}{*}{ Starter provision $(n=46)$} & From the 1 st wk of life & 35 & 76 & $63-90$ \\
\hline & From the 1 st mo of life & 11 & 24 & $11-37$ \\
\hline \multirow[t]{2}{*}{ Starter feed $(n=46)$} & $\begin{array}{l}\text { Formulated specially for pre-weaning } \\
\text { calves }\end{array}$ & 33 & 72 & $58-86$ \\
\hline & Other formulas & 13 & 28 & $14-42$ \\
\hline \multirow{2}{*}{$\begin{array}{l}\text { Hay provision during pre-weaning } \\
\text { period }(n=46)\end{array}$} & Yes & 12 & 26 & $12-40$ \\
\hline & No & 34 & 74 & $60-88$ \\
\hline
\end{tabular}

not a comprehensive udder health program. Similarly, in this study a gap related to calf health management was identified, representing different levels of intensification. Cluster analysis might be useful in understanding patterns of management that are not evident when analyzing the sampled population as a whole (Escobar and Berdegué, 1990). This information could be used for the design and implementation of specific advisory programs to improve herd management.

Only $63 \%$ of the visited farms registered birthdates of calves and from them, 296 calves and 467 heifers were evaluated. Figures 1 and 2 show the relationship of weight and height with age respectively. Estimated body gain during the pre-weaning period was $452 \mathrm{~g} / \mathrm{d}\left(\mathrm{R}^{2}=0.56\right)$, and $774 \mathrm{~g} / \mathrm{d}$ 
$\left(\mathrm{R}^{2}=0.43\right)$ for calves younger or older than $60 \mathrm{~d}$ of age, respectively (Figure 1). These results are similar to those of a previous report in Trenque Lauquen (Demateis Llera
\& Maekawa, 2015). The restricted amounts of milk fed to calves in the evaluated farms could explain the low growth rates achieved. Khan et al. (2007) reported similar growth

Table 4 - Herd descriptors about personnel area for the random sample of dairy farms from Trenque Lauquen, Argentina (2016)

\begin{tabular}{lcccc}
\hline \multicolumn{1}{c}{ Variables } & Classes & Number of farms & Frequency (\%) & Cl 95\% \\
\hline Technical support $(\mathrm{n}=44)$ & No & 7 & 15 & $4-28$ \\
& Continuously & 15 & 34 & $19-49$ \\
& Sporadically & 22 & 50 & $34-66$ \\
Exclusive personnel in pre-weaning & No & 30 & 68 & $53-83$ \\
area $(\mathrm{n}=44)$ & Yes & 14 & 32 & $17-47$ \\
Years in service $(\mathrm{n}=44)$ & 0.5 & 12 & 27 & $13-42$ \\
& $>2$ & 10 & 23 & $9-36$ \\
Formal education of person in & None & 22 & 50 & $34-66$ \\
charge of calves and heifers $(\mathrm{n}=43)$ & Primary school & 6 & 14 & $2-25$ \\
& Secondary school & 29 & 67 & $52-83$ \\
Informal training ( $\mathrm{n}=41)$ & Never & 21 & 51 & $6-31$ \\
& Once & 9 & 22 & $35-68$ \\
& $>$ once & 11 & 27 & $8-36$ \\
\hline
\end{tabular}

Table 5 - Characteristics of the farm clusters for the random sample of dairy farms $(n=46)$ from Trenque Lauquen, Argentina (2016)

\begin{tabular}{|c|c|c|c|}
\hline \multirow{2}{*}{ Variables } & \multirow{2}{*}{ Classes } & \multicolumn{2}{|c|}{ Frequency (\%) } \\
\hline & & Cluster $1(n=24)$ & Cluster $2(n=22)$ \\
\hline Systematic artificial colostrum feeding & Yes & 8 & 52 \\
\hline Prefresh cow vaccination & Yes & 16 & 67 \\
\hline \multirow[t]{2}{*}{ Prefresh pen } & Yes, permanent pen & 28 & 24 \\
\hline & Yes, alternating pens & 24 & 57 \\
\hline Navel disinfection & Yes & 36 & 71 \\
\hline Calf identification & Yes & 68 & 95 \\
\hline \multirow[t]{4}{*}{ Water provision } & All day long & 24 & 19 \\
\hline & Twice a day & 8 & 19 \\
\hline & Once a day & 56 & 52 \\
\hline & None & 12 & 10 \\
\hline \multirow[t]{2}{*}{ Weaning method } & Abrupt & 4 & 38 \\
\hline & Gradual & 96 & 62 \\
\hline Transition pen for weaned calves & Yes & 56 & 76 \\
\hline \multirow[t]{3}{*}{ Liquid feed type } & Waste milk & 76 & 29 \\
\hline & Saleable milk & 16 & 57 \\
\hline & Milk replacer & 8 & 14 \\
\hline \multirow[t]{3}{*}{ Liquid feed quantity } & $>4 \mathrm{~L} / \mathrm{d}$ & 84 & 61 \\
\hline & $4 \mathrm{~L} / \mathrm{d}$ & 4 & 10 \\
\hline & Stepped program & 12 & 29 \\
\hline \multirow[t]{2}{*}{ Starter provision } & From the 1 st wk of life & 76 & 76 \\
\hline & From the 1 st mo of life & 24 & 24 \\
\hline \multirow[t]{2}{*}{ Technical support } & Sporadically & 52 & 48 \\
\hline & Continuously & 24 & 48 \\
\hline \multirow[t]{3}{*}{ Years in service } & $<0.5$ & 40 & 10 \\
\hline & 0.5 to 2 & 24 & 19 \\
\hline & $>2$ & 36 & 71 \\
\hline \multirow[t]{2}{*}{ Formal education } & Primary school & 76 & 48 \\
\hline & Secondary school & 8 & 38 \\
\hline \multirow[t]{4}{*}{ Farm size (total cows) } & 60 to 120 & 48 & 19 \\
\hline & 121 to 200 & 24 & 14 \\
\hline & 201 to 300 & 24 & 24 \\
\hline & 301 to 400 & 4 & 34 \\
\hline
\end{tabular}


rates when calves were fed only $10 \%$ of their body weight (BW). Calves' height at $2 \mathrm{mo}$ of age was on average $80.2 \mathrm{~cm}$. This height was among the lower quartile in the standards published by Heinrichs et al. (2007).

Age, weight, and height distribution among total breeding heifers and farm averages are described in Table 6. In this study, the reported age at breeding was 5 to 7 mo older than recommended to achieve first calving at 22 to 24 mo of age (Heinrichs, 1993; Losinger \& Heinrichs, 1997), although they had already reached more than $55 \%$ of mature BW (assuming mature BW of 650-700 kg), as recommended by the Subcomitee on Dairy Cattle Nutrition (2001). Besides the

$\diamond 0$ to $60 \mathrm{~d} \quad>60 \mathrm{~d} \quad-\operatorname{Linear}(0$ to $60 \mathrm{~d}) \quad-\operatorname{Linear}(>60 \mathrm{~d})$

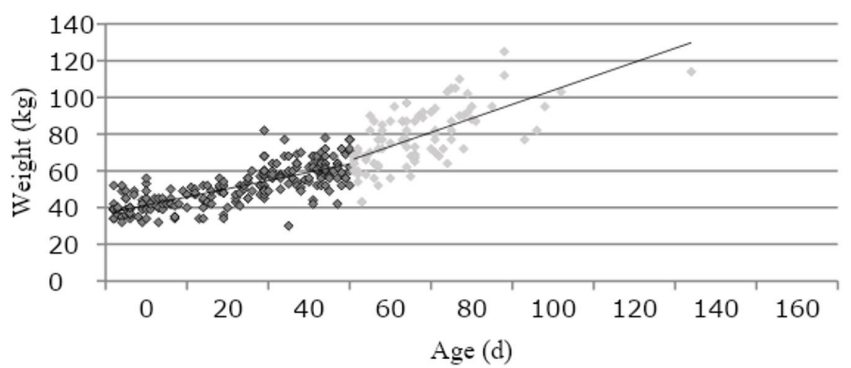

Figure 1 - Weight of different age calves during the pre-weaning period for the random sample of dairy farms $(n=40)$ from Trenque Lauquen, Argentina (2016).
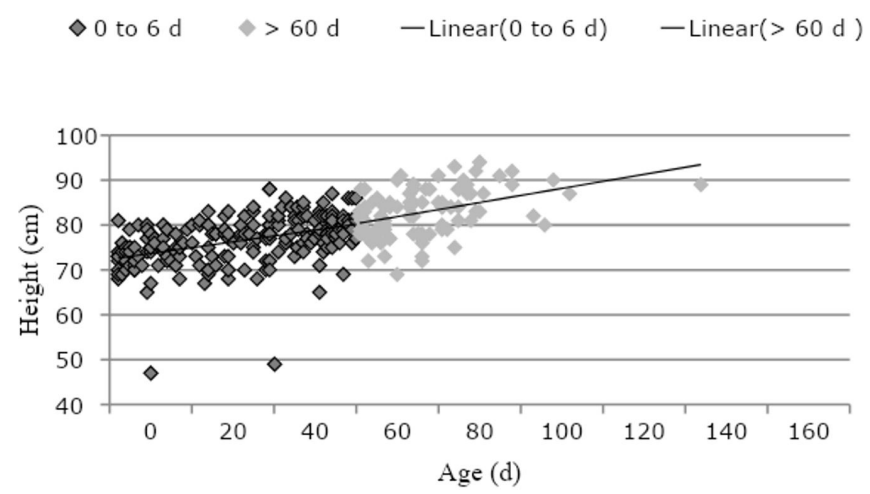

Figure 2 - Withers height of different age calves during the pre-weaning period for the random sample of dairy farms ( $n=40)$ from Trenque Lauquen, Argentina (2016). growth of the heifers, age at first breeding depends on the farmers' criteria to initiate breeding (Schuenemann et al.,2016), as demonstrated by our results with older and overweight heifers at breeding. Differences in breeding age and weight were observed between and within the herds, as reported by Brickell et al. (2009). Both within-herd variability and heifer overweight could be explained by inconsistencies in feeding, health, and general management during the rearing period (Heinrichs et al., 2005).

Diarrhea and respiratory affections in pre-weaning calves were evaluated in 40 farms. Although we found a farm average of $9.1 \%$ (IQ range $=0-12.5 \%$ ) in diarrhea prevalence, $5 \%$ of the farms showed values over $21 \%$. As expected, respiratory affections were a minor problem at the farm level, with only $5 \%$ of the farms with averages of $2.9 \%$ or higher. Of the 29 farms checked for disease prevalence in breeding heifers, only $10 \%$ showed high values of diarrhea ( $20 \%$ or higher). Regarding respiratory infections, the average prevalence was 5.8\% (IQ range $=0-6.7 \%$ ), with 3 farms over $20 \%$. Diarrhea was the main health issue in the pre-weaning period, as reported in other countries (McGuirk, 2008; García and Ruiz, 2013; Svensson et al., 2003), while respiratory problems were the most important in the rearing period (Callan and Garry, 2002).

Only 48,41 , and $35 \%$ of the farm owners could provide data about the number of dead animals at the calving, pre-weaning, and heifer rearing periods, respectively. Among those herds, median mortality was $7.3 \%$ at calving (Q1: 5.2 - Q3: 9.8), 7.6\% during the pre-weaning period (Q1: 5.0 - Q3: 10.5), and 2.9\% during the heifer rearing period (Q1: 1.4 - Q3: 4.0). In our country, lower mortality rates of 4.1 and $4 \%$ were reported in pre-weaning calves in Buenos Aires and Córdoba provinces, respectively (Larriestra, 1993; García and Ruiz, 2013). High mortality rates could affect heifer selection and culling rates, and both these factors negatively affect farm economics (Cabrera, 2012). Mortality rates obtained in this study could be underestimated. In general, farm owners who were able to provide health records may have been more prone to

Table 6 -Age, weight, and height distributions among total breeding heifers and farm averages $(\mathrm{n}=30)$ from Trenque Lauquen, Argentina (2016)

\begin{tabular}{|c|c|c|c|c|c|c|}
\hline & \multicolumn{2}{|c|}{ Age (mo) } & \multicolumn{2}{|c|}{ Weight (kg) } & \multicolumn{2}{|c|}{ Height (cm) } \\
\hline & $\begin{array}{l}\text { average } \\
\text { (range) }\end{array}$ & $\begin{array}{c}\text { interquartile } \\
\text { range }\end{array}$ & $\begin{array}{l}\text { average } \\
\text { (range) }\end{array}$ & $\begin{array}{c}\text { interquartile } \\
\text { range }\end{array}$ & $\begin{array}{l}\text { average } \\
\text { (range) }\end{array}$ & $\begin{array}{c}\text { interquartile } \\
\text { range }\end{array}$ \\
\hline \multirow{2}{*}{$\begin{array}{l}\text { Total heifers } \\
(n=464)\end{array}$} & 20.8 & $17-23.9$ & 410.7 & $345-470$ & 129.2 & $123.0-136.0$ \\
\hline & $(7.4-38.7)$ & & $(172-800)$ & & $(102.0-148.0)$ & \\
\hline \multirow{2}{*}{$\begin{array}{l}\text { Farm averages } \\
(n=15.5 \text { heifers/ } \\
\text { farm) }\end{array}$} & 21.0 & $19.0-22.5$ & 416.3 & $378.8-443.5$ & 129.7 & $126.6-132.5$ \\
\hline & $(16.7-27.5)$ & & $(336.7-519.3)$ & & $(121.6-137.8)$ & \\
\hline
\end{tabular}


have better management. This underestimation could be explained by the selection bias (Dargatz and Hill, 1996)

\section{Conclusion}

These results provide information about the most common practices in dairy farms about pre-fresh cows, colostrum management, pre-weaning calves' management, and personnel. It was possible to identify two farm profiles according to the degree to their good management practices adoption. A high mortality rate, as well as low growth rates and high BW among older heifers at breeding, were found. The findings highlight an opportunity for producers in terms of the identified practices to improve heifer replacement programs. It would be important to assess them through the development and implementation of precise, highimpact extension programs to improve the dairy farm replacement program.

\section{References}

Brandão AP, Cooke RF, Corrá FN, Piccolo MB, Gennari R, Leiva T, Vasconcelos JLM. Physiologic, health, and production responses of dairy cows supplemented with an immunomodulatory feed ingredient during the transition period. J Dairy Sci. 2016;99(7):5562-72. http://dx.doi. org/10.3168/jds.2015-10621. PMid:27085398.

Brickell JS, McGowan MM, Pfeiffer DU, Wathes DC. Mortality in Holstein-Friesian calves and replacement heifers, in relation to body weight and IGF-I concentration, on 19 farms in England. Animal. 2009;3(8):1175-82. http:// dx.doi.org/10.1017/S175173110900456X. PMid:22444847.

Buczinski S, Gicquel E, Fecteau G, Takwoingi Y, Chigerwe M, Vandeweerd JM. Systematic review and meta-analysis of diagnostic accuracy of serum refractometry and brix refractometry for the diagnosis of inadequate transfer of passive immunity in calves. J Vet Intern Med. 2018;32(1):47483. http://dx.doi.org/10.1111/jvim.14893. PMid:29210105.

Cabrera VE. A simple formulation and solution to the replacement problem: a practical tool to assess the economic cow value, the value of a new pregnancy, and the cost of a pregnancy loss. J Dairy Sci. 2012;95(8):4683-98. http:// dx.doi.org/10.3168/jds.2011-5214. PMid:22818482.

Callan RJ, Garry FB. Biosecurity and bovine respiratory disease. Vet Clin North Am Food Anim Pract. 2002;18(1):57-

\section{Conflict of interest}

The authors have no competing interests to declare.

\section{Ethics Statement}

At the time of this study, the animal care and use committee of the National Institute of Agricultural Technology (INTA) and the University of Buenos Aires reviewed animal experiments only when they interfered with health or welfare and this study was not the case.

\section{Acknowledgements}

The authors thank all the producers that gave us access to their farms and provided the information required and the National Institute of Agricultural Technology (INTA) and the University of Buenos Aires for financial support within the UBACyT program (Project 2018-2021, $\mathrm{N}^{\circ}$ 20020170100226BA).

77. http://dx.doi.org/10.1016/S0749-0720(02)00004-X. PMid:12064169.

Castel J, Madry W, Gozdowski D, Roszkowska-Madra B, Dabrowski M, Lupa W, Mena Y. Family dairy farms in the Podlasie province, Poland: farm typology according to farming system. Span J Agric Res. 2010;8(4):946-61. http:// dx.doi.org/10.5424/sjar/2010084-1390.

Dargatz DA, Hill GW. Analysis of survey data. Prev Vet Med. 1996;28(4):225-37. http://dx.doi.org/10.1016/01675877(96)01052-5.

Davis CL, Drackley JK. Desarrollo nutricion y manejo del ternero joven. 1st ed. Buenos Aires: Inter-Médica; 2001.

Demateis Llera FD, Maekawa M. Crianza de terneras Holando: resultados obtenidos en establecimientos lecheros, estudio de caso. Rev Argent Prod Anim. 2015;35(1):96.

Demateis Llera FD. Crianza de terneras holando: caracterización de sistemas de crianza en establecimientos lecheros. Memoria Técnica. 2015; 108-110.

Drackley JK. Calf Nutrition from birth to breeding. Vet Clin North Am Food Anim Pract. 2008;24(1):55-86. http:// dx.doi.org/10.1016/j.cvfa.2008.01.001. PMid:18299032. 
Dunn KM, Jordan K, Lacey RJ, Shapley M, Jinks C. Patterns of consent in epidemiologic research: evidence from over 25,000 responders. Am J Epidemiol. 2004;159(11):1087-94. http://dx.doi.org/10.1093/aje/kwh141. PMid:15155293.

Escobar G, Berdegué J. Tipificacion de sistemas de produccion agrícola. Santiago de Chile: Red Internacional de Metodologia de Investigación de Sistemas de Produccion; 1990. 284 p.

García JL, Ruiz G. Monitoreo de crianza artificial de terneros de tambo. In: Maresca S, Valiente SL, Cicchino, M, editors. INTA EEA Cuenca del Salado. Córdoba: Sitio Argentino de Producción Animal; 2013. p. 29-30.

Gargiulo JI, Eastwood CR, Garcia SC, Lyons NA. Dairy farmers with larger herd sizes adopt more precision dairy technologies. J Dairy Sci. 2018;101(6):5466-73. http://dx.doi. org/10.3168/jds.2017-13324. PMid:29525319.

Garry FB, Román-muñiz IN, Lombard JE, Van Metre DC. Dairy worker training in newborn calf management. In Smith RA, editor. American Association of Bovine Practitioners Proceedings of the Annual Conference; 2007 Sep 20-22; Vancouver, British Columbia. Stillwater: Frontier Printers, Inc. p. 33-7.

Gaspar P, Escribano M, Mesías FJ, Ledesma AR, Pulido F. Sheep farms in the Spanish rangelands (dehesas): typologies according to livestock management and economic indicators. Small Rumin Res. 2008;74(1-3):52-63. http://dx.doi. org/10.1016/j.smallrumres.2007.03.013.

Godden S. Colostrum management for dairy calves. Vet Clin North Am Food Anim Pract. 2008;24(1):19-39. http:// dx.doi.org/10.1016/j.cvfa.2007.10.005. PMid:18299030.

Greenacre MJ. Theory and applications of correspondence analysis. London: Academic Press; 1984.

Groenendaal H, Galligan DT, Mulder HA. An economic spreadsheet model to determine optimal breeding and replacement decisions for dairy cattle. J Dairy Sci. 2004;87(7):2146-57. http://dx.doi.org/10.3168/jds.S00220302(04)70034-X. PMid:15328228.

Hair JF, Black WC, Babin BJ, Anderson RE. Multivariate data analysis. Andover: Cengage; 1998.

Hammon HM, Schiessler G, Nussbaum A, Blum JW. Feed intake patterns, growth performance, and metabolic and endocrine traits in calves fed unlimited amounts of colostrum and milk by automate, starting in the neonatal period. J Dairy Sci. 2002;85(12):3352-62. http://dx.doi. org/10.3168/jds.S0022-0302(02)74423-8. PMid:12512608.

Heinrichs AJ, Erb HN, Rogers GW, Cooper JB, Jones CM. Variability in Holstein heifer heart-girth measurements and comparison of prediction equations for live weight. Prev Vet Med. 2007;78(3-4):333-8. http://dx.doi.org/10.1016/j. prevetmed.2006.11.002. PMid:17157398.

Heinrichs AJ, Heinrichs BS, Harel O, Rogers GW, Place NT. A prospective study of calf factors affecting age, body size, and body condition score at first calving of Holstein dairy heifers. J Dairy Sci. 2005;88(8):2828-35. http://dx.doi. org/10.3168/jds.S0022-0302(05)72963-5. PMid:16027197.

Heinrichs AJ. Raising dairy replacements to meet the needs of the 21st Century. J Dairy Sci. 1993;76(10):317987. http://dx.doi.org/10.3168/jds.S0022-0302(93)77656-0. PMid:8227639.

Hötzel MJ, Longo C, Balcão LF, Cardoso CS, Costa JHC. A survey of management practices that influence performance and welfare of dairy calves reared in southern Brazil. PLoS One. 2014;9(12):e114995. http://dx.doi.org/10.1371/journal. pone.0114995. PMid:25506692.

Hussain AM, Priya ICM. A study on training and development of employee at dairy industry private limited in Tiruvannamalai District. IJIR, 2016;(12):2105-8.

Jasper J, Weary DM. Effects of ad libitum milk intake on dairy calves. J Dairy Sci. 2002;85(11):3054-8. http://dx.doi. org/10.3168/jds.S0022-0302(02)74391-9. PMid:12487471.

Jenny BF, Gramling GE, Glaze TM. Management factors associated with calf mortality in South Carolina dairy herds. J Dairy Sci. 1981;64(11):2284-9. http://dx.doi.org/10.3168/ jds.S0022-0302(81)82843-3.

Kehoe SI, Jayarao BM, Heinrichs AJ. A survey of bovine colostrum composition and colostrum management practices on Pennsylvania dairy farms. J Dairy Sci. 2007;90(9):4108-16.

Kertz AF, Hill TM, Quigley JD 3rd, Heinrichs AJ, Linn JG, Drackley JKA. 100-year review: calf nutrition and management. J Dairy Sci. 2017;100(12):10151-72. http:// dx.doi.org/10.3168/jds.2017-13062. PMid:29153160.

Khan MA, Lee HJ, Lee WS, Kim HS, Ki KS, Hur TY, Suh GH, Kang SJ, Choi YJ. Structural growth, rumen development, and metabolic and immune responses of Holstein male calves fed milk through step-down and conventional methods. J 
Dairy Sci. 2007;90(7):3376-87. http://dx.doi.org/10.3168/ jds.2007-0104. PMid:17582123.

Kiezebrink DJ, Edwards AM, Wright TC, Cant JP, Osborne VR. Effect of enhanced whole-milk feeding in calves on subsequent first-lactation performance. J Dairy Sci. 2015;98(1):349-56. http://dx.doi.org/10.3168/jds.20147959. PMid:25468697.

Lagger J. Crecimiento intensivo de cría y recría de vaquillonas, aplicando los principios de bienestar. Rev Vet. 2010;27(265):1-28.

Larriestra AJ. Determinacion de factores de riesgo de mortalidad en terneros de lechería y evaluacion de su control mediante modelos de optimización [tesis]. Santiago: Universidad de Chile; 1993.

Losinger WC, Heinrichs AJ. An analysis of age and body weight at first calving for Holsteins in the United States. Prev Vet Med. 1997;32(3-4):193-205. http://dx.doi.org/10.1016/ S0167-5877(97)00018-4. PMid:9443327.

McGuirk SM. Disease management of dairy calves and heifers. Vet Clin North Am Food Anim Pract. 2008;24(1):139-53. http://dx.doi.org/10.1016/j.cvfa.2007.10.003. PMid:18299036.

Mee JF. Newborn dairy calf management. Vet Clin North Am Food Anim Pract. 2008;24(1):1-17. http://dx.doi. org/10.1016/j.cvfa.2007.10.002. PMid:18299029.

Mellado M, Lopez E, Veliz FG, Santiago MA, Macias-Cruz U, Avendaño-Reyes L, Garcia JE. Factors associated with neonatal dairy calf mortality in a hot-arid environment. Livest Sci. 2014;159(1):149-55. http://dx.doi.org/10.1016/j. livsci.2013.11.019.

Pereyra VG, Pol M, Pastorino F, Herrero A. Quantification of antimicrobial usage in dairy cows and preweaned calves in Argentina. Prev Vet Med. 2015;122(3):273-9. http://dx.doi. org/10.1016/j.prevetmed.2015.10.019. PMid:26558514.

Quigley JD 3rd, Drewry JJ. Nutrient and immunity transfer from cow to calf pre- and postcalving. J Dairy Sci. 1998;81(10):2779-90. http://dx.doi.org/10.3168/jds. S0022-0302(98)75836-9. PMid:9812284.

Raboisson D, Trillat P, Cahuzac C. Failure of passive immune transfer in calves: a meta-analysis on the consequences and assessment of the economic impact. PLoS One. 2016;11(3):e0150452. http://dx.doi.org/10.1371/journal. pone.0150452. PMid:26986832.
Rampone A, Vissio C, Bonetto C, Larriestra JA. Herd clustering base on milk quality practices in dairy milk producers from Córdoba, Argentina. In: Dájer A, editor. ISVEE XIV: Veterinary Epidemiology \& Economics: Planning Our Future; 2015. Merida, Yucatan. Yucatan: International Symposium of Veterinary.

Rocha GF, Bouda J, Cruz MM, Núñez OL, Yabuta OAK. Impacto de la administración y la calidad del calostro sobre los niveles de inmunoglobulinas séricas en becerros. Vet Méx. 1998;29(2):161.

Rosenberger K, Costa JHC, Neave HW, Keyserlingk MAG, Weary DM. The effect of milk allowance on behavior and weight gains in dairy calves. J Dairy Sci. 2017;100(1):504-12. http://dx.doi.org/10.3168/jds.2016-11195. PMid:27865513.

Roth BA, Keil NM, Gygax L, Hillmann E. Influence of weaning method on health status and rumen development in dairy calves. J Dairy Sci. 2009;92(2):645-56. http://dx.doi. org/10.3168/jds.2008-1153. PMid:19164677.

Schild CO, Caffarena RD, Gil A, Sánchez J, Riet-Correa F, Giannitti F. A survey of management practices that influence calf welfare and an estimation of the annual calf mortality risk in pastured dairy herds in Uruguay. J Dairy Sci. 2020;103(10):9418-29. http://dx.doi.org/10.3168/ jds.2020-18177. PMid:32773303.

Schuenemann GM, Piñeiro JM, Turiello P. Association between management practices and reproductive performance of lactating dairy cows. J. Anim. Sci. 2016;94(Suppl. 5):610. https://doi.org/10.2527/jam2016-1265.

Servicio Nacional de Sanidad y Calidad Agroalimentaria - SENASA [Internet]. 2018 [cited 2020 Dec 1]. Available from: http://www.senasa.gov.ar/prensa/DNSA/Control_ Gestion_y_Programas_Especiales/Indicadores_ganaderos/7_ Indicadores_Ganaderia_Bovina_\%20de_Tambo/Tambos. html.

Singleton RA, Straits B. Approaches to social research. 5th ed. New York: Oxford University Press; 2010. 672 p.

Subcomitee on Dairy Cattle Nutrition. Comitee on Animal Nutrition. National Research Council. Nutrient Requirements of Dairy Cattle. Washington: Washington National Academy Press; 2001. 401 p.

Svensson C, Lundborg K, Emanuelson U, Olsson S. Morbidity in Swedish dairy calves from birth to 90 days of age and individual calf-level risk factors for infectious diseases. Prev 
Vet Med. 2003;58(3-4):179-97. http://dx.doi.org/10.1016/ S0167-5877(03)00046-1. PMid:12706057.

Tao S, Monteiro APA, Thompson IM, Hayen MJ, Dahl GE. Effect of late-gestation maternal heat stress on growth and immune function of dairy calves. J Dairy Sci. 2012;95(12):7128-36. http://dx.doi.org/10.3168/jds.20125697. PMid:23021751.

Thrusfield MV, Christley R. Veterinary epidemiology. 4th ed. Oxford: Wiley Blackwell; 2018. 864 p. http://dx.doi. org/10.1002/9781118280249.

Tiranti K, Larriestra A, Vissio C, Picco N, Alustiza F, Degioanni A, Vivas A. Prevalence of Cryptosporidium spp. and Giardia spp., spatial clustering and patterns of shedding in dairy calves from Córdoba, Argentina. Rev Bras Parasitol Vet. 2011;20(2):140-7. http://dx.doi.org/10.1590/ S1984-29612011000200009. PMid:21722489.

Tiranti KM, Vissio CM, Larriestra AJM. Patrón de riesgo de la incidencia de diarrea y mortalidad en terneros de lechería en Córdoba, Argentina. Av Cienc Vet. 2015;30(1-2):1-9.
Ullah A, Zheng C. Why would dairy farmers care about human resource management practices? In: Ayoko R, editor. Australian \& New Zeland Academy of Management; 2011. Wellington, New Zeland. Melbourne, Australia: ANZAM. p. 1-19.

Vasseur E, Borderas F, Cue RI, Lefebvre D, Pellerin D, Rushen J, Wade KM, Passillé AM. A survey of dairy calf management practices in Canada that affect animal welfare. J Dairy Sci. 2010a;93(3):1307-16. http://dx.doi.org/10.3168/ jds.2009-2429. PMid:20172250.

Vasseur E, Rushen J, Passillé AM, Lefebvre D, Pellerin D. An advisory tool to improve management practices affecting calf and heifer welfare on dairy farms. J Dairy Sci. 2010b;93(9):4414-26. http://dx.doi.org/10.3168/jds.20092586. PMid:20723716.

Vissio C, Dieser SA, Raspanti CG, Giraudo JA, Bogni CI, Odierno LM, Larriestra AJ. Dairy herd mastitis program in argentina: farm clusters and effects on bulk milk somatic cell counts. Pak Vet J. 2013;33(1):80-4.

Financial Support: University of Buenos Aires, UBACyT program (Project 2018-2021, N 20020170100226BA). 